\author{
KATARZYNA GÓRSKA \\ ORCID: 0000-0002-3773-3617 \\ Uniwersytet Wrocławski \\ Instytut Prawa Cywilnego \\ Zakład Prawa Cywilnego i Prawa Międzynarodowego Prywatnego
}

\title{
O NIEKTÓRYCH PROBLEMACH REGULACJI FORMY CZYNNOŚCI PRAWNYCH
}

\begin{abstract}
Abstrakt: W dyskusji nad potrzebą i zakresem ewentualnej reformy regulacji formy czynności prawnych nie można tracić z pola widzenia podstawowych celów tej regulacji. Ma ona wskazywać przypadki, w których konieczne jest zachowanie formy szczególnej, określać na czym polega jej dochowanie i ustalać skutki niedochowania formy. Chociaż przepisy dotyczące formy mają niejednorodny charakter, z perspektywy legislacyjnej powinny być traktowane jako całość. Mając to na uwadze, artykuł porusza wybrane problemy regulacji formy czynności prawnych. Jego przedmiotem nie jest jednak ani szczegółowa analiza konkretnych przepisów, ani zaproponowanie rozwiązań de lege ferenda. Podstawowym celem opracowania jest zwrócenie uwagi na konieczność poszukiwania takich kierunków rozwiązań legislacyjnych, które zapewniałyby klarowność regulacji oraz jej systemową spójność i które mogłyby zostać przyjęte bez względu na ustalony model regulacji prawnej.
\end{abstract}

Słowa kluczowe: forma szczególna, regulacja prawna wymogów formalnych, forma pisemna, dokument, podpis, pismo, definicje legalne

\section{UWAGI WSTĘPNE}

Normatywne znaczenie regulacji formy czynności prawnych polega na rozróżnieniu przypadków, w których oświadczenie woli można złożyć dowolnie, oraz takich, w których przepis prawa wymaga zachowania pewnej określonej formy oraz ustala skutki jej niezachowania ${ }^{1}$. W pewnym uogólnieniu można stwierdzić, że od przepisów regulujących formę czynności prawnych należałoby oczekiwać przede wszystkim wskazania: przypadków, w których konieczne jest zachowanie określonej formy, sposobu dochowania formy oraz skutków, jakie powstaną w razie jej niedochowania. Należałoby się też spodziewać, że przepisy te — jako

\footnotetext{
1 S. Grzybowski, [w:] System Prawa Cywilnego, t. 1. Część ogólna, Wrocław 1974, s. 560.
} 
odnoszące się do sfery obowiązków nakładanych na podmioty prawa cywilnego ${ }^{2}$ - będą jak najlepiej realizować postulat określoności i pewności prawa.

De lege lata regulacja formy czynności prawnych w polskim prawie cywilnym obejmuje dwie główne grupy przepisów ${ }^{3}$. Pierwszą z nich są przepisy ogólne, do których należą normy określające typy podstawowych form szczególnych oraz skutki związane z ich niedochowaniem ${ }^{4}$. Ich dopełnieniem jest art. 60 k.c., który — zgodnie z przeważającym poglądem — daje podstawę do wyprowadzenia ogólnej dla stosunków prywatnoprawnych zasady swobody formy czynności prawnych. Cechą charakterystyczną całej tej grupy przepisów jest to, że z założenia mają mieć one zastosowanie do wszystkich typów czynności prawnych. Na drugą grupę składają się przepisy szczególne, których partykularny charakter polega nie tylko na tym, że w zależności od typu czynności prawnej ustawodawca decyduje o konieczności zachowania konkretnej formy, lecz także na tym, że ich umiejscowienie jest uzależnione od miejsca uregulowania czynności, której dotyczą.

Wskazany model regulacji formy czynności prawnych obowiązuje nieprzerwanie od momentu uchwalenia kodeksu cywilnego. Przepisy ogólne normujące formę czynności prawnych były wprawdzie kilkakrotnie nowelizowane, jednak nie zmieniło to generalnych założeń leżących u ich podstawy. Co przy tym znamienne, nowelizacji ogólnej regulacji formy nie towarzyszyła zazwyczaj adekwatna modyfikacja przepisów szczególnych. Tymczasem fragmentaryczne inicjatywy ustawodawcze i brak spojrzenia na regulację formy jako na pewną całość pogłębiało jej systemową niespójność 5 . Z tego względu wydaje się, że podstawowe wyzwanie, jakie stoi przed tym obszarem prawa prywatnego, wiąże się z koniecz-

$2 \mathrm{~W}$ literaturze zwracano uwagę, że normy konstruujące powinność zachowania formy szczególnej kreują obowiązek, którego niedopełnienie nie wywołuje typowych sankcji sprzężonych z niedopełnieniem obowiązku cywilnoprawnego, ale wywiera wpływ na samą czynność (zob. Z. Radwański, [w:] System Prawa Cywilnego, t. 1. Część ogólna, red. S. Grzybowski, Wrocław 1985, s. 620 n.). Jest to założenie aktualne, choć dość uogólnione. W konkretnych przypadkach skutki niedochowania formy szczególnej nie oddziałują wprost na dokonaną czynność prawną, lecz na przykład wpływają na treść stosunku cywilnoprawnego (jak niekiedy przy formie ad eventum). Jeszcze inaczej należałoby postrzegać skutki niedochowania formy przewidzianej dla oświadczeń innych niż oświadczenia woli (szerzej na ten temat w dalszej części opracowania). O charakterze norm zastrzegających wymogi formalne zob. M. Grochowski, Skutki braku zachowania formy szczególnej oświadczenia woli, Warszawa 2017, s. 6 n.

3 O klasyfikacji przepisów regulujących formę czynności prawnych zob. K. Górska, Zachowanie formy pisemnej czynności prawnych, Warszawa 2007, s. 7 n.; podobnie: M. Grochowski, op. cit., s. 18.

4 Aktualnie zawarte w księdze pierwszej k.c. w tytule IV poświęconym czynnościom prawnym. W ramach tego tytułu należy w pierwszej kolejności wymienić przepisy art. 73-81 k.c., zawarte w dziale III „Forma czynności prawnych” (ustawa z dnia 23 kwietnia 1964 roku — Kodeks cywilny, tekst jedn. Dz.U. z 2019 r. poz. 1145).

5 Ścisły związek pomiędzy różnymi typami przepisów regulujących formę dodatkowo uzasadnia pogląd, zgodnie z którym rekonstrukcja pełnej treści wymogu formalnego wymaga sięgnięcia do co najmniej dwóch przepisów (z których jeden ustanawia wymóg formalny, a drugi określa skutki jego niedochowania), leżących w różnych częściach systemu prawa-M. Grochowski, op. cit., s. 7. 
nością dokonania kompleksowej oceny stanu sformalizowania obrotu prawnego w celu ustalenia, czy i ewentualnie w jakim kierunku wymaga on modernizacji. Należałoby przy tym uwzględnić współczesne uwarunkowania, wytyczone przez postępującą automatyzację obrotu oraz proces europeizacji prawa prywatnego ${ }^{6}$, a w tym kontekście zrewidować aktualność celów zastrzeżenia konkretnych wymogów formalnych. Rzecz jasna, obszar tej analizy jest na tyle duży, że jej całościowe przeprowadzenie wydaje się mało realne, jednak można by postulować, aby jakakolwiek zmiana regulacji problematyki formy była oparta na jednolitych założeniach. W przeciwnym wypadku istnieje obawa, że kolejne, dokonywane ad hoc, nowelizacje będą się przyczyniać jedynie do zjawiska inflacji prawa.

Artykuł należy potraktować jako głos w dyskusji nad potrzebą i ewentualnym zakresem reformy regulacji formy czynności prawnych ${ }^{7}$. Rozważania zostaną sprowadzone do zasygnalizowania wybranych problemów, w związku z którymi można wziąć pod uwagę rewizję obowiązującego modelu unormowania formy czynności prawnych.

\section{KWESTIE TERMINOLOGICZNE}

Jest oczywiste, że język przepisów regulujących formę czynności prawnych powinien być możliwie jasny i zrozumiały dla przeciętnego odbiorcy. Tymczasem terminologia obowiązujących przepisów nastręcza pewnych trudności. Wynika to po części z nieprecyzyjnego zdefiniowania niektórych należących do formy pojęć lub kategorii, po części zaś z tego, że w stosunku do niektórych z nich pojawia się postulat rozszerzenia ich znaczeń w relacji do języka potocznego. Innym problemem jest to, że ustawodawca do opisania wymogów formalnych posługuje się zróżnicowaną terminologią, co utrudnia jednoznaczne określenie, jaki typ formy

${ }^{6}$ Wyrażana jest opinia, że zjawiska te wpływają na osłabienie znaczenia formy pisemnej, tradycyjnie uznawanej za podstawową w obszarze stosunków prywatnoprawnych. Akcentuje się też ewolucję funkcji przypisywanych formie czynności prawnych, polegającą między innymi na wzroście roli funkcji informacyjnej, zwłaszcza w ramach stosunków konsumenckich; na ten temat zob. M. Grochowski, Wymogi formalne w umowach konsumenckich, Warszawa 2018, s. 46 n.

7 Z uwagi na ramy opracowania nie będzie możliwe wiarygodne udzielenie odpowiedzi na pytanie, czy należy przyjąć nowy model regulacji formy, czy też wystarczy modyfikacja obecnego. Wątpliwości te odpowiadają ogólnemu dylematowi polskich cywilistów o zakres przebudowy kodeksu cywilnego. Warto zaznaczyć, że w zakresie problematyki formy opracowane współcześnie projekty nowego kodeksu cywilnego z 2009 i 2015 roku przyjęły dwie odrębne koncepcje regulacyjne; (projekt z 2009 roku opublikowany jako Księga pierwsza Kodeksu cywilnego. Projekt z uzasadnieniem, Warszawa 2009; projekt z 2015 roku opublikowany jako Kodeks cywilny. Księga pierwsza. Część ogólna. Projekt Komisji Kodyfikacyjnej Prawa Cywilnego przyjęty w 2015 r. z komentarzem członków zespołu problemowego, Warszawa 2017). Na obecnym etapie trudno przewidzieć, która z nich okaże się wiodącą. W niniejszym opracowaniu pomijam szczegółową analizę tych projektów, jednak niektóre propozycje w nich zawarte zostaną zasygnalizowane jako rozwiązania brane pod uwagę w pracach KKPC. 
szczególnej jest przewidziany oraz jakie czynności stron prowadzą do jego zachowania.

Niedostatek definicji legalnych w regulacji formy czynności prawnych sam W sobie nie jest zjawiskiem negatywnym ${ }^{8}$. W wypadku niektórych pojęć ustawodawca odwołuje się do instytucji formułowanych w języku prawniczym, których wyjaśnienie powinno należeć do doktryny prawa. Przykładem takiej sytuacji jest kategoria „formy czynności prawnych”, użyta jako nazwa działu III tytułu IV księgi I k.c. ${ }^{9}$ Niezdefiniowanie w ustawie niektórych pojęć jest też powodowane tym, że zostały one zaczerpnięte do języka prawniczego wprost $\mathrm{z}$ języka potocznego ${ }^{10}$. Ich rozumienie powinno być zatem zgodne z powszechnym, intuicyjnym odbiorem.

Brak definicji legalnych uzasadnia interwencję ustawodawcy, gdy przedstawiciele doktryny w swojej przeważającej większości nie mogą zgodzić się, jak rozumieć dane pojęcie lub kategorię prawną, a problemy te przenoszą się na poziom stosowania prawa i znajdują odzwierciedlenie w niejednolitej linii orzeczniczej ${ }^{11}$. W tym zakresie można zwrócić uwagę na przepisy regulujące, na czym polega wymóg zachowania formy szczególnej. Zachowanie definicyjnej jasności jest uzasadnione w odniesieniu do wszystkich wyróżnianych przez ustawodawcę ty-

8 Stosowanie definicji legalnych niesie z sobą ryzyko nasycenia przepisów językiem sztucznym, mało zrozumiałym w odbiorze przeciętnych adresatów prawa. Może też prowadzić do utrudnienia oceny relacji pomiędzy nimi; szerzej na ten temat zob. M. Bartoszewicz, Definicje legalne w świetle zasady określoności prawa, [w:] Dookoła Wojtek... Księga pamiątkowa poświęcona Doktorowi Arturowi Wojciechowi Preisnerowi, red. R. Balicki, M. Jabłoński, Wrocław 2018, s. 357.

${ }_{9}$ Według przeważającego poglądu przez formę czynności prawnych należy rozumieć każdy z możliwych przejawów woli. Przy okazji w nauce prawa zwraca się uwagę na nieścisłość tego wyrażenia, jako że w istocie rzeczy dotyczy ono formy oświadczenia woli, a nie formy całej czynności prawnej; tak m.in.: S. Grzybowski, op. cit., s. 560; Z. Radwański, op. cit., s. 620-621; S. Czepita et al., [w:] System Prawa Prywatnego, t. 2. Prawo cywilne - część ogólna, red. A. Olejniczak, Z. Radwański, wyd. 3, Warszawa 2019, s. 173. Takie rozumienie formy precyzuje P. Machnikowski, wskazując, że formą oświadczenia woli jest „rodzaj zachowania czy, szerzej, układu rzeczy i zjawisk (substratu materialnego), jakim posłużyła się osoba składająca oświadczenie woli (tworząca znak), aby ujawnić swój zamiar wywołania skutku prawnego (dokonać aktu regulowania stosunków cywilnoprawnych)" - idem, [w:] Kodeks cywilny. Komentarz, red. E. Gniewek, P. Machnikowski, wyd. 9, 2019, s. 142. W moim przekonaniu forma oświadczenia woli oznacza zarówno dobór znaków (na przykład określony zestaw słów lub gestów), ich postać (ustną lub pisemną) oraz ewentualny sposób utrwalenia (na przykład nośniki elektroniczne lub tradycyjne). W literaturze jest także artykułowany odmienny pogląd oddzielający kategorię formy oświadczenia woli (wyróżnianą na podstawie art. 60 k.c.) od formy czynności prawnych (o której ma być mowa w dziale III tytułu IV księgi I k.c.); na ten temat zob. W.J. Kocot, [w:] A. Brzozowski, W.J. Kocot, E. Skowrońska-Bocian, Prawo cywilne - część ogólna, Warszawa 2018, s. 300-301; L. Moskwa, Oświadczenie dorozumiane a swoboda formy czynności prawnych, „Ruch Prawniczy, Ekonomiczny i Społeczny” 1983, nr 1, s. 78.

10 Taka sytuacja ma obecnie miejsce w odniesieniu do pojęcia „podpisu”; na temat języka potocznego, zwanego też naturalnym, szerzej zob. A. Bator, [w:] Wprowadzenie do nauk prawnych. Leksykon tematyczny, red. A. Bator, wyd. 5, Warszawa 2016, s. 107.

11 Por. $\S 146$ ust. 1 rozporządzenia Prezesa RM z dnia 20 czerwca 2002 roku w sprawie „Zasad techniki prawodawczej” (tekst jedn. Dz.U. z 2016 r. poz. 283 ze zm.). 
pów form szczególnych. Jak wcześniej wskazano, przepisy prawa powinny jednoznacznie określać, na czym polega ustanowiony wymóg i jak należy go dopełnić. Wydaje się zatem, że regulacja formy czynności prawnych powinna obejmować wskazanie podstawowego katalogu form szczególnych wraz z ich zdefiniowaniem. Postulat ten jest obecnie realizowany tylko w pewnym stopniu, ponieważ de lege lata brakuje wyraźnych wskazań dotyczących formy z urzędowo poświadczoną datą czy formy z urzędowo poświadczonym podpisem ${ }^{12}$. Taki stan rzeczy zasługuje na uwagę ustawodawcy ${ }^{13}$.

Wprowadzanie definicji legalnych jest niecelowe w sytuacji, gdy ustawodawca posługuje się terminami należącymi do języka potocznego, o ile ich sens z założenia ma nie wykraczać poza ramy tego języka. W przeciwnym wypadku należy rozważyć ich ustawowe zdefiniowanie ${ }^{14}$. Gdyby zatem ustawodawca chciał rozszerzyć znaczenie podpisu własnoręcznego, o którym mowa w art. $78 \S 1$ k.c., poza ramy wyznaczone granicami języka potocznego, konieczne byłoby zastosowanie definicji legalnej ${ }^{15}$. Jeśli ustawodawca sięga do pojęć należących do języka specjalistycznego, to rzecz ma się zgoła inaczej. Artykuł $78^{1} \S 1$ k.c. odwołuje się do kategorii „kwalifikowanego podpisu elektronicznego”, bez wyjaśnienia, na czym ów podpis polega. Rozwiązanie wydaje się ryzykowne, dlatego że wprowadza do języka

12 Skutkuje to licznymi wątpliwościami interpretacyjnymi. Na temat kontrowersji wokół dochowania formy z urzędowo poświadczoną datą zob. K. Górska, O formie pisemnej z poświadczona data w nowym kodeksie cywilnym: uwagi w kontekście obowiąującej regulacji prawnej, „Rejent” 2010, $\mathrm{nr} 3$, i cytowana tam literatura; z kolei co do zachowania formy pisemnej z podpisem urzędowo poświadczonym zob. eadem, Ocena dochowania formy szczególnej czynności prawnej w aspekcie czasowym - uwagi na tle wyroku SN z dnia 29 stycznia 2009 r., V CSK 294/08, [w:] Wybrane zagadnienia polskiego prawa prywatnego. Księga pamiątkowa ku czci Dra J. Kremisa i Dra J. Strzebinczyka, red. J. Jezioro, K. Zagrobelny, Wrocław 2019, oraz cytowane tam piśmiennictwo.

13 Warto zwrócić uwagę, że projekty k.c. proponują w tym zakresie różne rozwiązania tego problemu. Projekt księgi I kodeksu cywilnego z 2009 roku zawiera w art. 104 § 2 k.c. wskazanie podstawowych typów formy szczególnej, do których zaliczono formę dokumentową, formę pisemną i jej kwalifikowane postaci (określone jako forma pisemna z poświadczoną datą, forma pisemna z poświadczonym podpisem, akt notarialny) oraz formę elektroniczną. W art. 106-112 projektu zaproponowano również definicje poszczególnych typów form; zob. Księga pierwsza Kodeksu cywilnego..., s. 115 n. Odmienne rozwiązanie przyjęto w projekcie z 2015 roku, w którym za zbędne uznano ustalenie katalogu wszystkich rodzajów form. Postanowiono, że nie ma potrzeby regulowania formy aktu notarialnego czy formy z urzędowo poświadczonym podpisem, jako że znajdują one swoje unormowanie w prawie o notariacie. W projekcie zaproponowano natomiast uregulowanie trzech zasadniczych (jak oceniono w uzasadnieniu projektu) przypadków form: formy podstawowej, formy identyfikującej oraz formy pisemnej; zob. Kodeks cywilny. Księga pierwsza..., s. 127 n. Oprócz tego w projekcie uregulowana została forma $\mathrm{z}$ datą pewną.

14 Taką decyzję podjął ustawodawca w odniesieniu do pojęcia dokumentu, którego szeroka formuła, wykraczająca poza tradycyjne rozumienie, została przewidziana $\mathrm{w}$ art. $77^{3} \mathrm{k}$.c.

15 Zaproponowano to w art. $90 \S 3$ projektu k.c. z 2015 roku, zgodnie z którym ,podpisem jest połączony z treścią oświadczenia ciąg znaków napisanych własnoręcznie umożliwiający ustalenie pochodzenia oświadczenia od osoby podpisującej, a także kwalifikowany podpis elektroniczny" Kodeks cywilny. Księga pierwsza..., s. 131. 
prawnego terminy, których znajomość jest zarezerwowana dla wąskiego grona odbiorców. Sytuacja jest dodatkowo niekorzystna, ponieważ znaczenie terminu jest wyjaśnione w ustawie pozakodeksowej, a definicja opiera się na pojęciach technologicznie zależnych, a więc z natury niestałych. W tym wypadku należałoby rozważyć modyfikację definicji kodeksowej formy elektronicznej w taki sposób, aby poprawić jej zrozumiałość i zapewnić technologiczną neutralność ${ }^{16}$.

Odrębnym zagadnieniem jest stosowanie w przepisach prawa nieujednoliconej terminologii w celu oznaczenia danego wymogu prawnego. Problem dotyczy wymogu formy pisemnej, dla którego ustanowienia ustawodawca posługuje się różnorodnymi sformułowaniami, typu: „wymaga formy pisemnej”, „,na piśmie”, „stwierdzone pismem” czy „pisemnie”. Dodatkowo sytuację skomplikowało tu wprowadzenie formy dokumentowej ${ }^{17}$. Stan ten powinno się poddać ustawowej korekcie, w myśl dobrej zasady, zgodnie z którą ustawodawca do oznaczenia jednakowych pojęć używa jednakowych określeń ${ }^{18}$.

\section{ANACHRONIZM SPOSOBU DEFINIOWANIA WYMOGÓW FORMALNYCH}

De lege lata formy szczególne są głównie definiowane przez wskazanie elementów koniecznych (minimalnych) do ich zrealizowania ${ }^{19}$. Przedmiotowe kryterium definiowania postaci form szczególnych jest wyrazem utrwalonej w polskim prawie cywilnym tradycji. Jednocześnie jednak naraża to regulację na zarzut, że w ten sposób dochodzi do petryfikacji form szczególnych w ramach wyznaczonych przez tradycyjne rozumienie tworzących ją elementów ${ }^{20}$. Alternatywą mogłoby być

16 W tym kierunku zmierza propozycja art. 108 § 1 projektu k.c. z 2009 roku, zgodnie z którym „dla zachowania formy elektronicznej należy złożyć oświadczenia woli w postaci danych elektronicznych, do których dołączono lub które logicznie powiązano z podpisem elektronicznym w sposób umożliwiający identyfikację składającego oraz wykrycie każdej późniejszej zmiany takiego oświadczenia” - Księga pierwsza Kodeksu cywilnego... Przeciwko swoistej ,informatyzacji” pojęcia podpisu elektronicznego na rzecz uwypuklenia jego elementów cywilnoprawnych opowiedział się też między innymi A.K. Bieliński w: idem, Charakter podpisu w polskim prawie cywilnym materialnym i procesowym, Warszawa 2007, s. 238.

17 Na mocy ustawy z dnia 10 lipca 2015 roku o zmianie ustawy — Kodeks cywilny, ustawy Kodeks postępowania cywilnego oraz niektórych innych ustaw (Dz.U. z 2015 r. poz. 1311) weszła ona w życie 8 września 2016 roku.

18 Zob. § 10 rozporządzenia w sprawie „Zasad techniki prawodawczej”. Na konieczność ujednolicenia terminologii jeszcze na etapie projektu regulacji wprowadzającej formę dokumentową zwracał uwagę między innymi M. Giaro w: idem, Cywilnoprawne pojęcie pisemności w społeczeństwie informacyjnym, „Państwo i Prawo” 2009, nr 10, s. 47.

19 Jedynie w wypadku formy dokumentowej ustawodawca stosuje kryterium odwołujące się do funkcji, jakie forma ta powinna realizować w obrocie.

20 M. Grochowski, Nowe koncepcje regulacji wymogów formalnych w prawie polskim, „Kwartalnik Prawa Prywatnego" 26, 2017, nr 4, s. 810. 
definiowanie wymogów formalnych przez odwołanie się do przypisywanych im funkcji. Wydaje się jednak, że błędem byłoby sprowadzanie tego dylematu wyłącznie do wyboru między przedmiotową (językową) a funkcjonalną metodą określenia form szczególnych. Każda z tych metod ma bowiem zarówno wady, jak i zalety.

Metoda przedmiotowa bezdyskusyjnie zapewnia większą jednoznaczność konstrukcji prawnej. Ocena dochowania formy polega w największym stopniu na sprawdzeniu, czy występują tworzące ją elementy. Forma staje się niejako bardziej „sformalizowana”, co upraszcza proces stosowania prawa zarówno z punktu widzenia stron, jak i sądów. Jednak mimo że ustalenie, na czym polega zachowanie formy szczególnej, staje się bardziej czytelne, nie musi być ono wolne od wątpliwości interpretacyjnych. Ich źródłem mogą być elementy współtworzące dany typ formy i to bez względu na to, czy ustawodawca je definiuje ${ }^{21}$, czy nie ${ }^{22}$. $\mathrm{W}$ takim wypadku rozstrzygnięcie ewentualnych niejasności będzie wymagało uwzględnienia aspektu funkcjonalnego. $\mathrm{Z}$ kolei zaletą wykorzystania metody funkcjonalnej przy definiowaniu formy szczególnej jest zapewnienie większej elastyczności konstrukcji prawnej, co pozwala na jej szersze wykorzystanie ${ }^{23}$. Metoda ta eksponuje też cel zastrzeżenia wymogu formalnego. Jednocześnie jednak otwiera możliwość zachowania formy szczególnej w wieloraki sposób, o ile tylko zapewni to realizację wskazanych przez ustawodawcę funkcji. W konsekwencji na strony przerzucony zostaje ciężar oceny, czy wybrany przez nie sposób złożenia oświadczenia woli wypełni wymóg formalny ${ }^{24}$. Sądy natomiast muszą dokonać oceny realizacji tego wymogu w kontekście przypisywanych mu funkcji ${ }^{25}$. Jest przy tym oczywiste, że taka ocena będzie in casu dokonywana z uwzględnieniem wykorzystanych przez strony konkretnych form przekazu. Ostatecznie prowadzi to do wniosku, że metoda definiowania wymogu formalnego ma drugorzędne znaczenie, ponieważ ocena jego dochowania w konkretnym wypadku może wymagać uwzględnienia zarówno aspektu przedmiotowego, jak i funkcjonalnego.

21 Jak w wypadku dokumentu, który stanowi element współtworzący formę pisemną. Mimo że pojęcie dokumentu zostało ustawowo zdefiniowane w art. $77^{3}$ k.c., można odnotować opinie, według których jest to definicja generująca problemy praktyczne — zob. m.in. W.J. Kocot, Dalsza modernizacja kodeksowej regulacji formy czynności prawnej, „Przegląd Prawa Handlowego” 2016, nr 10, s. 8 n.

22 Jak na przykład w wypadku podpisu.

${ }^{23} \mathrm{~W}$ odniesieniu do zdefiniowanej tą metodą formy dokumentowej pojawił się pogląd, że „za cenę jednoznaczności tworzonego pojęcia ustawodawca skonstruował definicję o szerokim polu zastosowania i dużej żywotności, mającą wiele zastosowań regulacyjnych" — M. Grochowski, Nowe koncepcje..., s. 821 .

${ }^{24} \mathrm{~W}$ tym kontekście pojawia się również pytanie o zakres kompetencji stron w doprecyzowaniu, w jaki sposób powinno być złożone oświadczenie przy dokonywaniu konkretnej czynności. W szczególności problematyczne może się okazać jednostronne „doprecyzowanie” wymogu formalnego przez tę stronę, która wykazuje przewagę kontraktową.

25 Jak zwraca uwagę M. Grochowski, zmienia to rolę sądu w odniesieniu do wymogu formalnego - idem, Nowe koncepcje...., s. 833. 
Uwspółcześnienie sposobu definiowania formy szczególnej może natomiast polegać na przełamywaniu stosowanej dotąd w przepisach konwencji, która przeważnie odpowiada językowi potocznemu. Jeśli przyjąć, że język ewoluuje wraz z rozwojem społecznym i gospodarczym, niewątpliwie może być to argument przemawiający za odpowiednią zmianą terminologii na poziomie ustawowym. W takim też kontekście należy czytać pojawiający się w literaturze postulat „rozluźnienia wymogów formy pisemnej”"26. Wydaje się jednak, że jakiekolwiek zmiany w tym zakresie nie powinny odbywać się w imię ogólnie pojętej „,nowoczesności", lecz powinny zawierać uzasadnienie polegające na konkretnym wskazaniu, w czym owa modyfikacja poprawi stosowanie prawa i jego rozumienie przez uczestników obrotu ${ }^{27}$. Przy zmianach na poziomie językowym należałoby również unikać wprowadzania terminów sztucznie skonstruowanych, nieprzystających do praktyki i niemających większego odniesienia do języka potocznego ${ }^{28}$.

Trzeba też dodać, że niektóre problemy związane z zachowaniem formy szczególnej znajdują się obecnie poza zakresem regulacji prawnej, co uzasadniałoby rozważenie jej uzupełnienia. Między innymi prawo nie określa, jakie elementy treści muszą być dokonane w przewidzianej formie, aby można było uznać, że doszło do realizacji wymogu ${ }^{29}$. Nieuregulowany jest także aspekt czasowy dochowania formy szczególnej ${ }^{30}$.

\section{PROBLEM SANKCJI Z TYTUŁU NIEDOCHOWANIA FORMY SZCZEGÓLNEJ}

Kodeks cywilny przewiduje trzy podstawowe rygory niedochowania formy szczególnej: nieważności (forma ad solemnitatem), dowodowy (forma ad probationem) i w celu wywołania szczególnych skutków prawnych (forma ad even-

${ }^{26}$ Ibidem, s. 809. Zob. też propozycję unormowania formy pisemnej w art. 90 projektu k.c. z 2015 roku — Kodeks cywilny. Księga pierwsza..., s. 131.

27 Taka potrzeba wydaje się szczególnie uzasadniona na tle sporu toczonego między zwolennikami separacji pojęć formy pisemnej i formy elektronicznej a zwolennikami koncepcji utworzenia jednej wspólnej konstrukcji obejmującej oba te sposoby złożenia oświadczenia woli.

${ }^{28} \mathrm{Z}$ tego względu z rezerwą można potraktować propozycje nazwania form szczególnych w projekcie k.c. z 2015 roku — zob. przyp. 16.

${ }^{29}$ Propozycję regulacji w tym zakresie przewiduje projekt k.c. z 2015 roku. Zgodnie z art. 86 projektu ,jeżeli ustawa wymaga dla dokonania czynności prawnej zachowania określonej formy, w formie tej powinna być wyrażona cała treść czynności, chyba że zastrzeżenie danego postanowienia bez zachowania wymaganej formy nie narusza celu, dla którego wymaganie formy ustanowiono. Dotyczy to także postanowień zawartych we wzorcu" — Kodeks cywilny. Ksiega pierwsza ..., s. 128.

${ }^{30}$ Rzecz z pozoru oczywista - wszak skoro oświadczenie musi być złożone w określonej formie, to zachowanie tego wymogu powinno być oceniane na moment jego złożenia. Komplikacje pojawiają się jednak w sytuacji, gdy formę szczególną współtworzą elementy dodatkowe, niezwiązane ściśle z uzewnętrznieniem woli; szerzej na ten temat zob. K. Górska, Ocena dochowania formy szczególnej..., s. $81 \mathrm{n}$. 
tum $)^{31}$. Najdalej idący jest rygor nieważności, przy czym - co warto zaznaczyć — powiązanie faktu niedochowania formy z tym skutkiem stanowi konsekwencję rozróżniania w nauce przesłanek istnienia oświadczenia woli od przesłanek jego ważności ${ }^{32}$. W rezultacie czynność prawną, w ramach której złożono oświadczenie woli bez zachowania formy wymaganej ad solemnitatem, uważa się za dokonaną, chociaż wadliwą. Takie podejście jest $\mathrm{z}$ kolei wyrazem emancypacji konstrukcji czynności prawnej polegającej na uniezależnieniu egzystencji czynności od formy jej dokonania ${ }^{33}$.

W odniesieniu do tego modelu od lat formułowany jest postulat zniesienia formy dla celów dowodowych jako niewystępującej w innych systemach prawnych i niepotrzebnie formalizującej obrót ${ }^{34}$. Pod jego wpływem kolejne nowelizacje wyeliminowały stosowanie tej formy w stosunkach profesjonalnych oraz zminimalizowały oddziaływanie związanych z nią sankcji w obrocie powszechnym i konsumenckim, aczkolwiek sama konstrukcja została utrzymana. Co więcej, po wprowadzeniu formy dokumentowej i formy elektronicznej, począwszy od 8 września 2016 roku, skutki formy dla celów dowodowych mogą być łączone nie tylko z niedochowaniem formy pisemnej, jak dotychczas, lecz także formy dokumentowej i elektronicznej. Celem tego rozwiązania było zapobieżenie nadmiernej formalizacji obrotu ${ }^{35}$.

Wprowadzenie formy dokumentowej miało bowiem z założenia realizować zgoła przeciwny cel. W efekcie jednak ustawodawca niejako „niechcący” stworzył szerszy grunt pod wykorzystanie instytucji, którą innymi sposobami stara się systematycznie ograniczać. Taką sytuację trudno ocenić jako zadowalającą.

31 Polski system sankcji odzwierciedla pod tym względem wpływy, jakie na kształtowanie się rodzimego prawa miały ustawodawstwa obce, zwłaszcza prawo niemieckie (gdy chodzi o sankcję nieważności) oraz francuskie (gdy chodzi o sankcję dowodową); szerzej na ten temat zob. R. Longchamps de Bérier, Polskie prawo cywilne. Zobowiązania, wyd. 2, Lwów 1939 (wydanie anastatyczne Poznań 1999), s. 106 n.

32 Takie podejście było podstawą regulacji kodeksu zobowiązań, który następnie w dużym stopniu posłużył jako podstawa obecnego kodeksu cywilnego; zob. R. Longchamps de Bérier, op. cit., s. 76. Forma nie stanowiła przesłanki istnienia oświadczenia woli, w tym sensie, że uznawano, iż prawo wiąże skutki prawne z każdym oświadczeniem, nawet dorozumianym; o przesłankach oświadczenia woli w tym kontekście zob. R. Longchamps de Bérier, Czynności prawne, [w:] Encyklopedja Prawa Prywatnego, Warszawa-Bydgoszcz 1931, s. 1, https://dlibra.kul.pl/dlibra/publication/41597/edition/37764/content (dostęp: 15.05.2020).

33 Forma przestała być postrzegana jako element konstytuujący czynność prawną; zob. S. Czepita et al., op. cit., s. 173.

34 Współcześnie na temat krytyki tej instytucji obszerniej zob. K. Górska, O perspektywie zniesienia formy pisemnej dla celów dowodowych w nowym kodeksie cywilnym, „Rejent” 2008, nr 14; co do oceny tej instytucji po nowelizacji k.c. z 2016 roku zob. M. Grochowski, Forma ad probationem po nowelizacji kodeksu cywilnego z 10.07.2015 r., „Rejent” 2016, nr 11; oraz M. Giaro, Dwie kwestie formy ad probationem w nowym art. 74 \& 3 KC, „Przegląd Sądowy” 2016, nr 9.

35 Miałoby to miejsce, gdyby do formy dokumentowej lub elektronicznej stosować art. $73 \S 2$ k.c. w brzmieniu sprzed nowelizacji, wedle którego rygor nieważności był podstawowym skutkiem niedochowania formy szczególnej, innej niż pisemna. 
Forma dla celów dowodowych, będąc instytucją o wydźwięku głównie procesowym, ma - z racji uchylających jej rygor okoliczności ${ }^{36}$ — znaczenie marginalne. $Z$ tego względu sens zastrzegania tej formy można podawać w wątpliwość. Bez względu jednak na to, czy i ewentualnie kiedy ustawodawca zdecyduje się ostatecznie dokonać całkowitego zniesienia formy ad probationem, należałoby oczekiwać dokonania szczegółowego przeglądu czynności, do których znajduje ona zastosowanie, w celu rozważenia, czy w konkretnej sytuacji zasadne jest jej utrzymywanie ${ }^{37}$.

Istniejący system sankcji z tytułu niedochowania formy szczególnej naraża się na krytykę również z tego powodu, że jest nieadekwatny do sytuacji, w których rygor niedochowania formy należy odnieść nie do oświadczenia woli, lecz do oświadczenia wiedzy ${ }^{38}$. Problem nie jest nowy, jednak jego skala znacząco wzrosła w związku z pojawieniem się pod wpływem prawa unijnego licznych regulacji odnoszących się do konieczności zachowania wymogów formalnych na etapie przedkontraktowym, głównie w obrocie konsumenckim. Artykuł $65^{1}$ k.c., wedle którego ,przepisy o oświadczeniach woli stosuje się odpowiednio do innych oświadczeń", mimo że formalnie daje podstawę do odpowiedniego stosowania do tej kategorii oświadczeń przepisów o formie czynności prawnych, nie usuwa wątpliwości co do tego, jak w konkretnym wypadku powinny być oceniane skutki niezachowania formy oświadczenia wiedzy. Sankcja nieważności, której istota sprowadza się do niewywołania zamierzonego skutku prawnego, nie może być odnoszona do oświadczeń wiedzy, które choć niepozbawione znaczenia normatywnego, nie mają charakteru celowego i tym różnią się od oświadczeń woli, że nie są ukierunkowane na wywołanie skutku prawnego w postaci powstania, zmiany lub zniesienia stosunku prawnego ${ }^{39}$. Niecelowe byłoby również stosowanie sankcji dowodowych.

W literaturze zwraca się wobec tego uwagę, że oświadczenie wiedzy złożone z uchybieniem formy wymaganej w ustawie nie wywoła skutków prawnych, jakie przepisy wiążą z oświadczeniem wiedzy o określonej treści i w odpowiedniej

36 Por. art. 74 § $2-4$ k.c.

37 Całkowite zniesienie formy w celach dowodowych zostało zaproponowane w obu projektach nowego kodeksu cywilnego — z 2009 i 2015 roku. Propozycje te wyznaczają kierunek legislacyjny na przyszłość, jednak nie przesądzają związanych z nimi skutków. Całościowe konsekwencje wynikające ze zniesienia formy w celach dowodowych będą uzależnione, po pierwsze, od tego, jakim innym rygorem zostanie zastąpiona dotychczasowa forma ad probationem; po drugie, w stosunku do jakich czynności rygor ten zostanie zastosowany.

38 W literaturze wskazuje się, że sankcje z tytułu niedochowania formy szczególnej zostały zaprojektowane z myślą o oświadczeniach woli i dostosowane do ich specyfiki, wobec czego nawet odpowiednie ich stosowanie do oświadczeń wiedzy jest zabiegiem utrudnionym; zob. M. Grochowski, Nowe koncepcje..., s. 813-815; P. Machnikowski, op. cit., s. 162.

$39 \mathrm{Na}$ temat charakteru prawnego oświadczeń wiedzy zob. P. Rodziewicz, Oświadczenia wiedzy po nowelizacji Kodeksu cywilnego z dnia 10.7.2015 r., „Wrocławskie Studia Sądowe” 2016, nr 2, s. $95 \mathrm{n}$. 
formie $^{40}$. Pogląd ten najbardziej zbliża rygor niedochowania formy oświadczenia wiedzy do formy ad eventum. Oznacza on jednak konieczność badania skutków niedochowania wymogów formalnych indywidualnie w odniesieniu do konkretnych oświadczeń wiedzy. Nie można przy tym wykluczyć, że w niektórych przypadkach owe szczególne skutki niedochowania formy nie zawsze będą możliwe do jednoznacznego ustalenia.

Radykalną propozycję systemowego uregulowania tej kwestii zawiera projekt kodeksu cywilnego z 2015 roku. Wyraża on całkowicie nową koncepcję regulacyjną, polegającą na odejściu od obecnego modelu sankcji. Podstawowym skutkiem wynikającym z niedochowania formy szczególnej ma być bowiem uznanie, że dane oświadczenie nie zostało złożone ${ }^{41}$. $\mathrm{Z}$ uzasadnienia warte przytoczenia są przy tym dwa stwierdzenia: po pierwsze, iż proponowany przepis jest spójny $\mathrm{z}$ założeniem, że kwestia formy dotyczy przesłanek prawnie doniosłego sposobu złożenia oświadczenia woli; po drugie, że takie rozwiązanie zapewni spójność sankcji nie tylko wobec oświadczeń woli, lecz także oświadczeń wiedzy ${ }^{42}$.

O ile jednak bez większych zastrzeżeń można by zgodzić się z drugim z nich, to pierwsze wskazuje na istotne przebudowanie przez projektodawców nie tylko modelu sankcji z tytułu niedochowania formy, lecz przede wszystkim samej koncepcji oświadczenia woli, którego byt zostałby użależniony od wymaganej formy. Rezygnacja z rygoru nieważności dla czynności prawnej z uwagi na niezachowanie wymaganej formy oświadczenia woli musi oznaczać zmianę w stosunku do klasycznego postrzegania w doktrynie przesłanek warunkujących byt oświadczenia woli i odróżniania ich od przesłanek jego ważności ${ }^{43}$.

\section{AUTOMATYZACJA OBROTU PRAWNEGO}

Automatyzacja i cyfryzacja obrotu prawnego jest dziś zjawiskiem powszechnym. Masowy charakter mają umowy zawierane z wykorzystaniem elektronicznych środków komunikacji. Znane są również kontrakty, w których do złożenia oświadczenia woli dochodzi nawet bez udziału stron ${ }^{44}$. Wydaje się jednak, że mimo tej ultranowoczesności zautomatyzowane sposoby kontraktowania sta-

40 Szerzej na ten temat zob. M. Grochowski, Nowe koncepcje..., s. 815; P. Rodziewicz, op. cit., s. 103.

${ }^{41}$ Zgodnie z projektowanym art. $87 \S 1$,jeżeli ustawa albo czynność prawna zastrzegająca zachowanie formy nie stanowi inaczej, w razie niezachowania wymaganej formy oświadczenie uważa się za niezłożone".

42 Zob. Kodeks cywilny. Księga pierwsza..., s. 129.

${ }^{43}$ Zob. wcześniejsze uwagi, s. 343. O konsekwencjach braku formy w kontekście rygoru nieważności i skutku w postaci nieistnienia czynności prawnej zob. M. Grochowski, Skutki braku zachowania formy..., s. $95 \mathrm{n}$.

${ }^{44}$ Chodzi o tak zwane inteligentne umowy (smart contracts), w których o zawarciu umowy przesądza wcześniej zaprogramowany algorytm. 
nowią wyzwanie dla regulacji formy o tyle, o ile dotyczą czynności, w stosunku do których ustawodawca przewiduje wymóg zachowania formy szczególnej. W przeciwnym wypadku — zgodnie z wyrażoną w art. 60 k.c. zasadą swobody formy - strony uczestniczące w obrocie elektronicznym mogą swobodnie decydować o sposobie składania w nim różnego typu oświadczeń i nie są związane przewidzianymi w ustawie typami form. Odformalizowanie obrotu przez ustawodawcę dałoby więc szerszą możliwość dokonywania czynności prawnych z wykorzystaniem dowolnie wybranych środków komunikacji elektronicznej. Wymagałoby to kompleksowej analizy i oceny, w jakim zakresie aktualne wymogi formalne mogą zostać zniesione lub złagodzone.

W obszarze ogólnej regulacji formy czynności prawnych wpływ automatyzacji obrotu prawnego może być zauważalny w tym sensie, że przepisy te określają typy form szczególnych, które w tym obrocie znajdują (lub mogą znaleźć) zastosowanie. Innymi słowy, chodzi o przewidzenie takich form komunikacji elektronicznej, w których da się zrealizować istniejący wymóg formalny.

Po nowelizacji kodeksu cywilnego z 2016 roku $^{45}$ przepisy ogólne przewidują w zasadzie trzy postaci form szczególnych, które mogą być wykorzystane w obrocie elektronicznym. Należą do nich formy: dokumentowa (art. $77^{2}$ k.c.), elektroniczna (art. $78^{1} \S 1$ k.c.) oraz forma $\mathrm{z}$ kwalifikowanym elektronicznym znacznikiem czasu (art. $81 \S 2$ pkt 3 k.c.). Dodatkowo, z uwagi na ustalenie szerokiej definicji dokumentu (art. $77^{3}$ k.c.), nie można wykluczyć możliwości wykorzystania go w obrocie elektronicznym jako samodzielnej postaci formy szczególnej. Zakres stosowania tych form zależy przede wszystkim od tego, w jakim stopniu przepisy szczególne będą przewidywać obowiązek ich zachowania. Na pewno można sobie wyobrazić i w pełni zaaprobować szersze niż aktualnie zastosowanie formy dokumentowej. Mogłoby to nastąpić między innymi przez zastąpienie istniejącego obecnie wymogu formy pisemnej formą dokumentową ${ }^{46}$. Odpowiedzią na rosnące potrzeby obrotu mogłoby być również ustanowienie dla tradycyjnych form szczególnych ich odpowiedników w postaci elektronicznej.

De lege lata jedynie w stosunku do zwykłej formy pisemnej przewidziano możliwość jej zastąpienia przez formę elektroniczną (art. $78^{1} \S 2$ k.c.) ${ }^{47}$. Ustawodawca uzależnia jednak taką możliwość od opatrzenia oświadczenia woli w postaci elektronicznej kwalifikowanym podpisem elektronicznym, co - z uwagi na skomplikowaną i kosztowną procedurę jego uzyskania — znacząco ogranicza możliwość wykorzystania tej formy jako odpowiednika formy pisemnej. Uzasad-

45 Dz.U. z 2015 r. poz. 1311.

46 Tak też postuluje W.J. Kocot, Dalsza modernizacja..., s. 11.

47 Wyrażona w tym przepisie reguła ekwiwalentności ma - począwszy od 7 października 2016 roku — charakter bezwzględny. Przed tą datą możliwość zastąpienia formy pisemnej formę elektroniczną mogła być wyłączona mocą ustawy lub z woli stron. Opisana zmiana art. $78^{1} \S 2$ k.c. nastąpiła na podstawie art. 51 ustawy z dnia 5 września 2016 roku o usługach zaufania oraz identyfikacji elektronicznej (tekst jedn. Dz.U. z 2019 r. poz. 162). 
niałoby to postulat rozluźnienia wymagań stawianych kwalifikowanemu podpisowi elektronicznemu, jednak możliwość jego uwzględnienia wymagałaby szczegółowego rozważenia w kontekście wiążących Polskę norm prawa europejskiego ${ }^{48}$.

Poza tym przepisy prawa cywilnego nie przewidują elektronicznych odpowiedników form o wyższym stopniu sformalizowania niż forma pisemna. Szczególnym przełomem w tym obszarze mogłoby być uregulowanie elektronicznego aktu notarialnego, co zrewolucjonizowałoby dokonywanie czynności w obrocie nieruchomościami oraz w prawie korporacyjnym. Obecnie tradycyjna forma aktu notarialnego nie ma swojego elektronicznego odpowiednika. Da się jednak zauważyć proces digitalizacji, gdy chodzi o przechowywanie i wydawanie aktów notarialnych ${ }^{49}$, co być może zainicjuje prace nad kolejnym etapem polegającym na dopuszczeniu możliwości dokonywania czynności notarialnych w postaci elektronicznej.

\title{
SOME PROBLEMS OF THE FORM REQUIREMENTS REGULATION
}

\author{
Summary
}

In the discussion on the need and scope of the possible reform of form requirements regulations, one must not lose sight of the basic purposes of these regulations. It is intended to indicate cases in which it is necessary to maintain a specific form, to determine what is necessary to maintain it and to determine the consequences of failure of a specific form. Although the provisions on the form are heterogeneous in nature, they should be considered as the whole from a legislative perspective. Considering this, the article deals with selected problems of form requirements regulations. However, it is neither a detailed analysis of specific provisions nor a proposal for de lege ferenda solutions. The main aim of the study is to draw attention to the need to look for such directions of legislative solutions which would ensure the clarity of regulation and its systemic coherence and which could be adopted regardless of the established model of legal regulations.

Keywords: specific form, form requirements regulations, written form, document, signature, writing, legal definitions

48 Por. art. 25 w związku z definicjami przewidzianymi w art. 3 Rozporządzenia PE i Rady (UE) NR 910/2014 z dnia 23 lipca 2014 roku w sprawie identyfikacji elektronicznej i usług zaufania w odniesieniu do transakcji na rynku wewnętrznym oraz uchylającym dyrektywę 1999/93/WE. (Dz Urz. UE L Nr 257, s. 73). Jest jednak wyrażana opinia, zgodnie z którą polska transpozycja tej dyrektywy przewiduje surowsze wymagania stawiane kwalifikowanemu podpisowi elektronicznemu niż sama dyrektywa.

49 Od 9 kwietnia 2018 roku działa tak zwane Centralne Repozytorium Elektronicznych Wypisów Aktów Notarialnych (CREWAN), prowadzone w systemie teleinformatycznym przez Krajową Radę Notarialną, gdzie obligatoryjnie umieszczane mają być przez notariuszy elektroniczne wypisy aktów notarialnych zawierających dane będące podstawą wpisu w rejestrze przedsiębiorców KRS albo podlegających złożeniu do akt rejestrowych podmiotu wpisanego do rejestru przedsiębiorców KRS; zob. art. 92a ustawy z dnia 14 lutego 1991 roku — Prawo o notariacie (tekst jedn. Dz.U. z 2019 r. poz. 540 ze zm., obowiązujący od 15 marca 2018 roku). 


\section{BIBLIOGRAFIA}

Bartoszewicz M., Definicje legalne w świetle zasady określoności prawa, [w:] Dookoła Wojtek... Księga pamiątkowa poświęcona Doktorowi Arturowi Wojciechowi Preisnerowi, red. R. Balicki, M. Jabłoński, Wrocław 2018.

Bator A., [w:] Wprowadzenie do nauk prawnych. Leksykon tematyczny, red. A. Bator, wyd. 5, Warszawa 2016.

Bieliński A.K., Charakter podpisu w polskim prawie cywilnym materialnym i procesowym, Warszawa 2007

Czepita S., Drozd E., Kuniewicz Z., Radwański Z., Słotwiński S., [w:] System Prawa Prywatnego, t. 2. Prawo cywilne - część ogólna, red. A. Olejniczak, Z. Radwański, wyd. 3, Warszawa 2019.

Giaro M., Cywilnoprawne pojęcie pisemności w społeczeństwie informacyjnym, „Państwo i Prawo” 2009, nr 10.

Giaro M., Dwie kwestie formy ad probationem w nowym art. $74 \xi 3$ KC, „Przegląd Sądowy” 2016, nr 9.

Górska K., O formie pisemnej z poświadczoną data w nowym kodeksie cywilnym: uwagi w kontekście obowiazującej regulacji prawnej, „Rejent” 2010, nr 3.

Górska K., O perspektywie zniesienia formy pisemnej dla celów dowodowych w nowym kodeksie cywilnym, „Rejent” 2008, nr 14.

Górska K., Ocena dochowania formy szczególnej czynności prawnej w aspekcie czasowym - uwagi na tle wyroku SN z dnia 29 stycznia 2009 r., V CSK 294/08, [w:] Wybrane zagadnienia polskiego prawa prywatnego. Ksiega pamiatkowa ku czci Dra J. Kremisa i Dra J. Strzebinczyka, red. J. Jezioro, K. Zagrobelny, Wrocław 2019.

Górska K., Zachowanie formy pisemnej czynności prawnych, Warszawa 2007.

Grochowski M., Forma ad probationem po nowelizacji kodeksu cywilnego z 10.07.2015 r., „Rejent” 2016, nr 11 .

Grochowski M., Nowe koncepcje regulacji wymogów formalnych w prawie polskim, „Kwartalnik Prawa Prywatnego" 26, 2017, z. 4.

Grochowski M., Skutki braku zachowania formy szczególnej oświadczenia woli, Warszawa 2017.

Grochowski M., Wymogi formalne w umowach konsumenckich, Warszawa 2018.

Grzybowski S., [w:] System Prawa Cywilnego, t. 1. Część ogólna, Wrocław 1974.

Kocot W.J., [w:] A. Brzozowski, W.J. Kocot, E. Skowrońska-Bocian, Prawo cywilne - część ogólna, Warszawa 2018.

Kocot W.J., Dalsza modernizacja kodeksowej regulacji formy czynności prawnej, „Przegląd Prawa Handlowego" 2016, nr 10.

Kodeks cywilny. Księga pierwsza. Część ogólna. Projekt Komisji Kodyfikacyjnej Prawa Cywilnego przyjęty w 2015 r. z komentarzem członków zespołu problemowego, Warszawa 2017.

Księga pierwsza Kodeksu cywilnego. Projekt z uzasadnieniem, Warszawa 2009.

Longchamps de Bérier R., Czynności prawne, [w:] Encyklopedja Prawa Prywatnego, Warszawa-Bydgoszcz 1931, https://dlibra.kul.pl/dlibra/publication/41597/edition/37764/content.

Longchamps de Bérier R., Polskie prawo cywilne. Zobowiązania, wyd. 2, Lwów 1939 (wydanie anastatyczne Poznań 1999).

Machnikowski P., [w:] Kodeks cywilny. Komentarz, red. E. Gniewek, P. Machnikowski, wyd. 9, Warszawa 2019.

Moskwa L., Oświadczenie dorozumiane a swoboda formy czynności prawnych, „Ruch Prawniczy, Ekonomiczny i Społeczny" 1983, nr 1.

Radwański Z., [w:] System Prawa Cywilnego, t. 1. Część ogólna, Wrocław 1985.

Rodziewicz P., Oświadczenia wiedzy po nowelizacji Kodeksu cywilnego z dnia 10.7.2015 r., „Wrocławskie Studia Sądowe" 2016, nr 2. 